\title{
The Impact of Antiviral Therapy and the Influence of Metabolic Cofactors on the Outcome of Chronic HCV Infection
}

\author{
Marcello Persico, ${ }^{1}$ Savino Bruno, ${ }^{2}$ Andrea Costantino, ${ }^{3}$ \\ Marta Mazza, ${ }^{3}$ and Piero Luigi Almasio ${ }^{3}$ \\ ${ }^{1}$ Internal Medicine and Hepatology Division, Second University of Naples, Via Del Parco Carelli 36, 80123 Naples, Italy \\ ${ }^{2}$ Department of Internal Medicine, AO Fatebenefratelli e Oftalmico, Corso di Porta Nuova 23, 20121 Milano, Italy \\ ${ }^{3}$ Gastroenterology \& Hepatology Unit, Di.Bi.M.I.S., University of Palermo, Piazza delle Cliniche, 2, 90127 Palermo, Italy
}

Correspondence should be addressed to Marcello Persico, marcello.persico@unina2.it

Received 30 December 2010; Revised 9 August 2011; Accepted 18 August 2011

Academic Editor: Richard Guan

Copyright ( $) 2011$ Marcello Persico et al. This is an open access article distributed under the Creative Commons Attribution License, which permits unrestricted use, distribution, and reproduction in any medium, provided the original work is properly cited.

\begin{abstract}
Natural history of HCV related chronic hepatitis is influenced and modified by many factors: virus features, coinfections and host characteristics. In particular, a peculiar genetic background of the host by conditioning the occurrence of intracellular metabolic derangements (i.e., insulin resistance) might contribute to accelerate the rate of progression to cirrhosis and eventually the occurrence of hepatocellular carcinoma (HCC) and death. Likely, direct interplays between virus genotype and host genetic background might be hypothesized at this level. Morbidity and mortality in cirrhosis is primarily associated with complications of liver cirrhosis (ascites, hepatic encephalopathy, jaundice, and gastroesophageal bleeding) and HCC occurrence. Therefore the main goal of therapy is to clear viral infection and decrease liver necro-inflammation that directly relates to development of cirrhosis and HCC. Among patients treated with Interferon-based therapy, those with sustained viral response showed a significant reduction of progression to cirrhosis and development of HCC. However, a residual risk of hepatocellular carcinoma still remains indicating the need for careful follow-up using ultrasonography every six months in cirrhotic patients, even in those showing persistently normal ALT and undetectable HCV RNA levels after antiviral therapy.
\end{abstract}

\section{Introduction}

The natural history of HCV infection is usually characterized by the transition from no perceivable acute to chronic infection, which may progress from a long-lasting asymptomatic condition up to a decompensated hepatic disease and/or hepatocellular carcinoma (HCC) development, which represents the main cause of liver-related death and liver transplantation in the Western World [1-5] (Figure 1). One hundred seventy million of people are infected worldwide, more than 30 million are affected by cirrhosis, and the incidence of HCC is about 1-2 million new cases/year. The actual estimated incidence is markedly decreased, and this is attributable to the employment of a safe transfusion's screening policy with a very high decrease number of new infections.

Recovery from acute infection is estimated to occur in $10-25 \%$ of patients, and the onset of the disease remains largely unknown since it is symptomless in the vast majority of cases. Moreover, since the availability of effective therapies has led to treat patients, the outcome and natural history of untreated people in order to analyse the events, their timing, and type of evolution has not been fully evaluated [612]. Furthermore, another essential phenomenon that has hampered the difficulty to obtain reliable information of the progression of the disease is because many cofactors can change the rate of progression of the disease. In particular, alcohol consumption together with other several factors (iron overload, hepatic steatosis, metabolic syndrome, viral coinfections) may play an important role in accelerating the progression of the disease [13].

A wide range of study designs (i.e., case-series, crosssectional, case-control, cohort, clinical trial) has been developed in clinical investigation, and, among them, cohort studies have been largely employed. This type of studies 


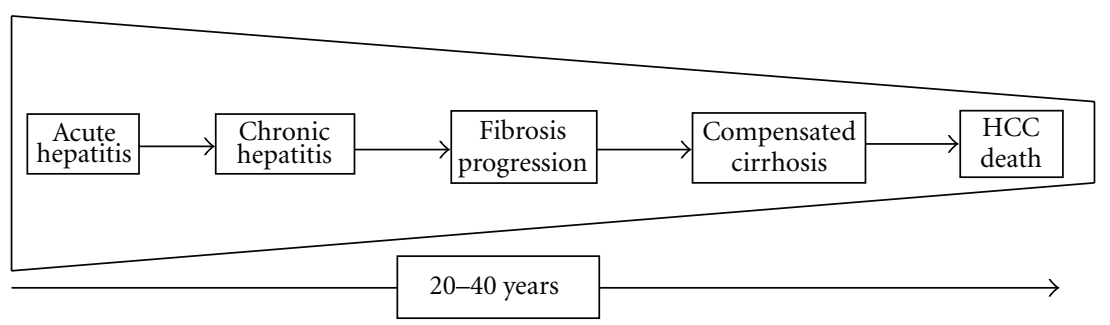

FIGURE 1: Natural history of chronic HCV infection.

represents a valid approach to by-pass the above-mentioned difficulties to assess the natural history of HCV infection. In fact, based on the statistical concept of "analysis by segments," a typical approach for the cohort studies, the progression of HCV infection can be designed as the sequence of different, limited, and of presumably known duration stages of the disease.

\section{Natural History of HCV Infection}

2.1. Studies Estimating Disease Progression. To define the natural history of an infectious disease, it is mandatory to establish the time of infection, to define the onset of the symptoms, to prospectively monitor expected end-points, to record the occurrence of risk factors (alcohol, other viruses, metabolic disorders, etc.), and to follow untreated patients for a long period of time. Unfortunately, although any possible HCV infection was demonstrable since 1989 [14], there is no hope to find such data in the studies published on this topic and a great heterogeneity among them might be mostly due to the diversity in the design of the studies themselves. In fact, in retrospective cohort studies, the presence of cirrhosis was ascertained in $17 \%$ up to $55 \%$ of chronic infected adults, and HCC in $1 \%$ up to $23 \%$ $[15,16]$; on the other hand, in prospective cohort studies, the rate of progression to cirrhosis was of $7 \%$ to $16 \%$ and HCC of $0.7 \%$ to $1.3 \%$ per year $[6,17,18]$. In retrospectiveprospective cohort studies, the prognosis of patients with chronic hepatitis $\mathrm{C}(\mathrm{CHC})$ was reported as benign and only a minority of the infected subjects ultimately developed cirrhosis $[19,20]$. Similarly, Vogt and coworkers described a low rate of liver disease occurrence in children who underwent cardiac surgery before the implementations of the new rules for blood-donors screening [21]. By contrast, other studies reported a relative high rate of cirrhosis [22, 23], and, in particular, $5.9 \%$ of cirrhosis and liver-related death was found in a small cohort of anti-HCV US military recruits during a 45-year follow-up study [24].

2.2. Prognostic Factors of Disease Progression. A long-lasting elevated necroinflammatory activity seems to play a crucial role in the progression of the disease, and this clinical evidence seems to be supported also by data from patients with persistently normal ALT. Within this peculiar context, no progression of the disease was found at a second liver biopsy taken after 5 years of followup, with the exception of subjects in which the occurrence of flares-up seemed modifying the benign course of the disease [25-27]. However, even if the biochemistry is only partially indicative, no other reliable marker able to predict the progression of the disease has been identified so far. Moreover, the prognosis of subjects infected by HCV can also be affected by different variables, and many factors, either virus-related or host-related, have been investigated in order to understand the natural history of this infection.

2.3. Viral Factors. Regardless the evidence that genotype $1 \mathrm{~b}$ more than genotype 2 was reported to be associated with the development of HCC [28] and with a poor outcome of the disease [28-30], no data are available, so far, about other HCV genotypes. By contrast, while the viral load seems not to be associated with the histology activity index, it has relevant implications rather with viral response to therapy [31-34]. The presence of other viral coinfections (i.e., HIV, HBV) speeds up the clinical course of the disease $[35,36]$. The coinfection with HBV is most common in several highrisk populations, such as injection drug users (IDU) $[37,38]$, patients on hemodialysis [39], patients undergoing organ transplantation [40], HIV-positive individuals [41, 42], and $\beta$-thalassemia patients $[43,44]$. In all these categories, liver injury was more severe in terms of progression of fibrosis and liver cirrhosis, hepatic decompensation [45-50]. Moreover in this subgroup has been shown an increased risk of developing HCC [51-53]. Also, the presence of HIV has a negative impact on the natural history of $\mathrm{HCV}$ since the progression to cirrhosis is higher in coinfected $[54,55]$. HCV/HIV coinfection is associated to develop other complications, such as hematologic disorders [56, 57], kidney disease $[58,59]$, cardiovascular disease $[60,61]$, and neurologic status [62-65].

2.4. Host Factors. Among the host-related factors, female gender and young age seem to influence the outcome of $\mathrm{CHC}[66]$. In the last few years, another important aspect represented by the presence of comorbidities was shown to impact on the evolution of chronic HCV infection. Hepatic steatosis, obesity, and/or an insulin resistance must be considered important determinants of the disease progression [67-70]. Recent data also show that genotype 1 might specifically interfere with a peculiar host genetic background conditioning an altered intracellular insulin signalling [71, 72]. However, the relationship between body mass, insulin resistance, steatosis, and clinical outcomes is still complex. In study of long-term peginterferon treatment (HALT-C), 
the modifiable risk factors for liver disease progression were studied, and insulin resistance was strongly associated with outcomes [73]. On the other hand, the significance of both iron overload and "occult" HBV infection remains still controversial [74-77]. The iron overload plays an important role. The complexity of the interplay between iron and $\mathrm{CHC}$ is underscored by recent finding that mutations in $H F E$, particularly the common $\mathrm{H} 63 \mathrm{D}$ variation, while being associated with higher hepatic and total body iron, is also related to a significantly higher likelihood of complete and sustained responses to antiviral therapy [78]. A recent study shows that stainable iron in hepatocytes and portal tract cells is a predictor of progression and clinical and histological outcomes in advanced chronic hepatitis $\mathrm{C}$ while chronic administration low-dose of peginterferon did not improve outcomes, nor iron variables [79].

2.5. External Factors. Among investigated cofactors, the alcohol abuse is the most important one which can dramatically change the course of the disease. Persistent intake even of low alcohol amount may seriously interfere with the progression of the disease [80]. Alcohol consumption, even at low daily intake, has been proposed as a risk factor for the progression of liver disease in chronic HCV infection [81, 82]. Alcohol consumption has a very significant impact on both the histologic and clinical progression of chronic HCV infection. The mechanisms whereby alcohol enhances HCV infection and histologic damage are still unclear [83].

Geographical differences in the evolution of chronic $\mathrm{HCV}$ infection to cirrhosis should also be considered: in USA, and Europe, this percentage is almost 15\% (range $8 \%-24 \%$ ), but in Japan it ranges between $30 \%$ and $46 \%$. Similarly, the percentage of evolution to HCC is $0.7 \%-1.3 \%$ in Western countries, but significantly higher in the Far East and Japan where the rate ranges from $10 \%$ to $19 \%$ [84].

\section{The Natural Course of HCV-Induced Cirrhosis}

The natural history of HCV-induced chronic liver disease remains poorly measurable. As discussed above, a practical approach used to by-pass the above-mentioned difficulties is represented by the "analysis by segments" [85-88]. All these studies agreed that the development of HCC represents the main cause of death in cirrhotic patients and male sex, older age, high alpha-fetoprotein levels, and HBV coinfection were considered the main risk factors of development of the tumor. Interestingly, some studies have also described as risk of HCC occurrence the presence of oesophageal varices $[29,89]$. The presence of gastrooesophageal varices is commonly considered an important risk factor of hepatic decompensation, and certainly they are expression of portal hypertension. Based on this assumption, the hypothesis that explains the association between varices and HCC development is based on the assumption that an impaired regional blood flow due to portal hypertension might determine local hypoxia which stimulates the synthesis of angiogenic factors [90]. Moreover, HCV genotype $1 \mathrm{~b}$ was recently confirmed as a risk factor associated with HCC development in a prospective study [91, 92]. Accordingly, a biological plausibility has been recently provided showing a possible interplay by HCV and a cellular oncosuppressor determining a linkage between a mutated viral site and a different sensitive to damage-induced apoptosis [93].

Taking into account all the available information, patterns of progression to cirrhosis are very different: fast if it occurs in less than 20 years, intermediate in $20-50$ years, slow in more than 50 years. Moreover, in some patients, there is no progression at all. The causes of this divergence in outcome are still poorly understood. However, survival at 5 years is reduced to 50\% after an episode of decompensation [94-96].

Future studies on the natural history of HCV disease should be aimed to identify patients with high risk of disease progression and to assess the impact of therapy on disease outcome.

\section{The Impact of Antiviral Therapy on Natural Course of the Disease}

The lack of randomised studies hampers a reliable estimation of the impact of antiviral treatment on the long-term outcome of patients with HCV infection. Several cohort studies, designed to assess the response to Interferon (IFN) therapy in cirrhotic patients, documented a better prognosis for patients who received IFN regardless of HCV-RNA eradication. Two retrospective reports [97, 98] confirmed these data, and altogether these studies have demonstrated that sustained virological response (SVR) is significantly associated with a reduction of decompensation rate, HCC occurrence, and liver-related mortality. Therefore, liver disease morbidity and mortality is dependent on successful antiviral therapy, and peginterferon plus ribavirin is, at present time, the treatment of choice before direct-acting antivirals (DAAs) will be available [99].

4.1. Progression from Chronic Hepatitis $C$ to Cirrhosis. The assessment of histological activity and fibrosis stage of liver biopsies performed before and after antiviral treatment remains the most reliable parameter to evaluate short-term benefit of viral clearance. In 487 Japanese patients who underwent paired liver biopsy, samples obtained from 1 to 10 years apart showed a regression of fibrosis related to SVR [100]. Accordingly, other European studies by analyzing the impact of SVR on the long-term clinical outcome of chronic hepatitis C concluded that SVR was significantly associated with a decrease in fibrosis score [11,101-103]. More recently, George et al. demonstrated in a large cohort that clinical, virologic, biochemical, and histological outcomes of patients followed up to 5 years after SVR are favourable, and recovery of normal or nearly normal liver architecture is possible [104].

The available literature on the likelihood of progression to cirrhosis in treated patients is limited [105-117]. Once SVR is achieved the histological progression is uncommon (7 out of 1,662 treated patients with SVR) (Table 1). On the contrary, in relapsers or nonresponder patients, the rate of 
TABLE 1: Cumulative rate of development of cirrhosis in patients with HCV-related chronic hepatitis according to sustained viral response (SVR); n/a: not available.

\begin{tabular}{|c|c|c|c|c|c|}
\hline Author & Reference & $\begin{array}{l}\text { Treated } \\
\text { patients }\end{array}$ & $\begin{array}{l}\text { Followup } \\
\text { (years) }\end{array}$ & $\begin{array}{c}\text { Rate of cirrhosis } \\
\text { after SVR }\end{array}$ & $\begin{array}{c}\text { Rate of cirrhosis } \\
\text { in absence of } \\
\text { SVR }\end{array}$ \\
\hline Marcellin et al. & {$[105]$} & 450 & $1-7.6$ & $0 / 75$ & $\mathrm{n} / \mathrm{a}$ \\
\hline Sata et al. & {$[106]$} & 63 & $0.6-3.8$ & $0 / 25$ & 9/38 (23.7\%) \\
\hline Lau et al. & [107] & 10 & $10-13$ & $0 / 5$ & $2 / 5(40.0 \%)$ \\
\hline Cammà et al. & {$[108]$} & 62 & $0.7-9$ & $0 / 62$ & $5 / 360(1.3 \%)$ \\
\hline Ajello et al. & {$[109]$} & 31 & 10 & $1 / 10(10.0 \%)$ & $\mathrm{n} / \mathrm{a}$ \\
\hline Morisco et al. & [110] & 191 & 4 & $0 / 39$ & $12 / 115(10.4 \%)$ \\
\hline Gallego et al. & [111] & 79 & 4 & $0 / 11$ & $33 / 87(37.9 \%)$ \\
\hline Giannini et al. & {$[112]$} & 36 & $1-6$ & $0 / 15$ & $3 / 21(14.3 \%)$ \\
\hline Shindo et al. & [113] & 250 & $8-11$ & $0 / 67$ & $62 / 183(33.9 \%)$ \\
\hline Swain et al. & [114] & 997 & 8 & 0/989 & 8/997 (0.8\%) \\
\hline Veldt et al. & [115] & 343 & 1.6 & $6 / 110(5.5 \%)$ & $3 / 15(20 \%)$ \\
\hline Ciancio et al. & {$[116]$} & 97 & 7 & $0 / 83$ & $3 / 86(3.5 \%)$ \\
\hline \multirow[t]{2}{*}{ Chavalitdhamrong and Tanwandee } & [117] & $\mathrm{n} / \mathrm{a}$ & 3 & $0 / 171$ & $27 / 171(15.8 \%)$ \\
\hline & & & & $7 / 1,662(0.42 \%)$ & $\begin{array}{c}162 / 2,078 \\
(7.8 \%)\end{array}$ \\
\hline
\end{tabular}

disease evolution to cirrhosis is much more frequent (162 out of 2,078).

4.2. Progression from Compensated to Decompensated Cirrhosis and Hepatocellular Carcinoma. Unsatisfactory SVR rates have been attained in patients with cirrhosis when using traditional monotherapy regimens of recombinant IFN alfa or peginterferon [118], and all clinical trials for drug registration considered decompensated liver disease as an exclusion criterion [119-122]. In these studies, SVR rates were calculated by pooling together patients with different degree of hepatic fibrosis, ranging from marginal bridging fibrosis to compensated cirrhosis. As a consequence, no definite conclusion could be reached about the efficacy and safety of treatment in this cohort of patients. Nevertheless, results emerging from these studies suggested that treatment of patients with well-compensated HCV-induced cirrhosis using PEG-IFN alfa-2b plus RBV may be considered a reliable option in "easy to treat" "genotypes" (2a/c, 3a), while in the "difficult to treat" ones (1a, $1 b$ and 4 genotype), the results are not satisfactory. In this subgroup of patients, the use of baseline and on-treatment predictors of response may enhance virologic outcomes and refinement of the regimens investigated is warranted. Further studies are also needed to develop treatment schedules for individual genotype populations.

\section{Summary}

Natural history of HCV-related chronic hepatitis is conditioned by virus features, coinfections, and host characteristics. In particular, a peculiar genetic background of the host by conditioning the occurrence of intracellular metabolic derangements (i.e., insulin resistance) might contribute to accelerate the rate of progression to cirrhosis and eventually the occurrence of HCC. Likely, direct interplays between virus genotype and host genetic background might be hypothesized at this level.

Morbidity and mortality in cirrhosis is primarily associated with complications of liver cirrhosis and HCC occurrence. Therefore, the main goal of therapy is to inhibit viral replication and decrease liver necroinflammation that directly relates to development of cirrhosis and HCC.

Among patients treated with IFN-based therapy, those with SVR showed a significant reduction of progression to cirrhosis and development of HCC. However, a residual risk of hepatocellular carcinoma still remains indicating the need for careful followup using ultrasonography every six months in cirrhotic patients, even in those showing persistently normal ALT and undetectable HCV RNA levels after antiviral therapy.

\section{References}

[1] G. Fattovich, M. Pantalena, I. Zagni, G. Realdi, S. W. Schalm, and E. Christensen, "Effect of hepatitis B and $\mathrm{C}$ virus infections on the natural history of compensated cirrhosis: a cohort study of 297 patients," American Journal of Gastroenterology, vol. 97, no. 11, pp. 2886-2895, 2002.

[2] L. Serfaty, H. Aumaître, O. Chazouillères et al., "Determinants of outcome of compensated hepatitis $\mathrm{C}$ virus-related cirrhosis," Hepatology, vol. 27, no. 5, pp. 1435-1440, 1998.

[3] K. Q. Hu and M. J. Tong, "The long-term outcomes of patients with compensated hepatitis $\mathrm{C}$ virus- related cirrhosis and history of parenteral exposure in the United States," Hepatology, vol. 29, no. 4, pp. 1311-1316, 1999.

[4] L. Benvegnù, M. Gios, S. Boccato, and A. Alberti, "Natural history of compensated viral cirrhosis: a prospective study on the incidence and hierarchy of major complications," Gut, vol. 53, no. 5, pp. 744-749, 2004. 
[5] G. Fattovich, G. Giustina, F. Degos et al., "Morbidity and mortality in compensated cirrhosis type C: a retrospective follow-up study of 384 patients," Gastroenterology, vol. 112, no. 2, pp. 463-472, 1997.

[6] M. P. Manns, J. G. McHutchison, S. C. Gordon et al., "Peginterferon alfa-2b plus ribavirin compared with interferonalfa$2 \mathrm{~b}$ plus ribavirin for initial treatment of chronic hepatitis C: a randomised trial," The Lancet, vol. 358, no. 9286, pp. 958 965, 2001.

[7] M. W. Fried, M. L. Shiffman, K. Rajender Reddy et al., "Peginterferon alfa-2a plus ribavirin for chronic hepatitis $\mathrm{C}$ virus infection," The New England Journal of Medicine, vol. 347, no. 13, pp. 975-982, 2002.

[8] J. G. Mchutchison, S. C. Gordon, E. R. Schiff et al., "Interferon alfa-2b alone or in combination with ribavirin as initial treatment for chronic hepatitis C," The New England Journal of Medicine, vol. 339, no. 21, pp. 1485-1492, 1998.

[9] S. J. Hadziyannis, H. Sette Jr., T. R. Morgan et al., "Peginterferon-alpha2a and ribavirin combination therapy in chronic hepatitis C: a randomized study of treatment duration and ribavirin dose," Annals of Internal Medicine, vol. 140, no. 5, pp. 346-355, 2004.

[10] S. L. George, B. R. Bacon, E. M. Brunt, K. L. Mihindukulasuriya, J. Hoffman, and A. M. Di Bisceglie, "Clinical, virologic, histologic, and biochemical outcomes after successful HCV therapy: a 5-year follow-up of 150 patients," Hepatology, vol. 49, no. 3, pp. 729-738, 2009.

[11] B. J. Veldt, E. J. Heathcote, H. Wedemeyer et al., "Sustained virologic response and clinical outcomes in patients with chronic hepatitis C and advanced fibrosis," Annals of Internal Medicine, vol. 147, no. 10, pp. 677-684, 2007.

[12] V. Di Marco, P. L. Almasio, D. Ferraro et al., "Peg-interferon alone or combined with ribavirin in HCV cirrhosis with portal hypertension: a randomized controlled trial," Journal of Hepatology, vol. 47, no. 4, pp. 484-491, 2007.

[13] L. Serfaty, A. Poujol-Robert, N. Carbonell, O. Chazouillères, R. E. Poupon, and R. Poupon, "Effect of the interaction between steatosis and alcohol intake on liver fibrosis progression in chronic hepatitis C," American Journal of Gastroenterology, vol. 97, no. 7, pp. 1807-1812, 2002.

[14] G. Kuo, Q. L. Choo, H. J. Alter et al., "An assay for circulating antibodies to a major etiologic virus of human non-A, non-B hepatitis," Science, vol. 244, no. 4902, pp. 362-364, 1989.

[15] L. B. Seeff, "Natural history of chronic hepatitis C," Hepatology, vol. 36, no. 5, pp. S35-S46, 2002.

[16] M. J. Tong, N. S. El-Farra, A. R. Reikes, and R. L. Co, "Clinical outcomes after transfusion-associated hepatitis C," The New England Journal of Medicine, vol. 332, no. 22, pp. 1463-1466, 1995.

[17] A. M. Di Bisceglie, Z. D. Goodman, K. G. Ishak, J. H. Hoofnagle, J. J. Melpolder, and H. J. Alter, "Long-term clinical and histopathological follow-up of chronic posttransfusion hepatitis," Hepatology, vol. 14, no. 6, pp. 969-974, 1991.

[18] R. L. Koretz, H. Abbey, E. Coleman, and G. Gitnick, "Non-A, non-B post-transfusion hepatitis: looking back in the second decade," Annals of Internal Medicine, vol. 119, no. 2, pp. 110115, 1993.

[19] E. Kenny-Walsh and F. Shanahan, "Clinical outcomes after hepatitis C infection from contaminated anti-D immune globulin," The New England Journal of Medicine, vol. 340, no. 16, pp. 1228-1233, 1999.

[20] M. Wiese, F. Berr, M. Lafrenz, H. Porst, and U. Oesen, "Low frequency of cirrhosis in a hepatitis $\mathrm{C}$ (genotype $1 \mathrm{~b}$ ) single- source outbreak in Germany: a 20-year multicenter study," Hepatology, vol. 32, no. 1, pp. 91-96, 2000.

[21] M. Vogt, T. Lang, G. Frösner et al., "Prevalence and clinical outcome of hepatitis $\mathrm{C}$ infection in children who underwent cardiac surgery before the implementation of blood-donor screening," The New England Journal of Medicine, vol. 341, no. 12, pp. 866-870, 1999.

[22] L. B. Seeff, F. B. Hollinger, H. J. Alter et al., "Long-term mortality and morbidity of transfusion-associated non-A, nonB, and type C hepatitis: a National Heart, Lung, and Blood Institute Collaborative Study," Hepatology, vol. 33, no. 2, pp. 455-463, 2001.

[23] A. J. Rodger, S. Roberts, A. Lanigan, S. Bowden, T. Brown, and N. Crofts, "Assessment of long-term outcomes of community-acquired hepatitis $\mathrm{C}$ infection in a cohort with sera stored from 1971 to 1975," Hepatology, vol. 32, no. 3, pp. 582$587,2000$.

[24] L. B. Seeff, R. N. Miller, C. S. Rabkin et al., "45-Year follow-up of hepatitis $\mathrm{C}$ virus infection in healthy young adults," Annals of Internal Medicine, vol. 132, no. 2, pp. 105-111, 2000.

[25] M. Persico, E. Persico, R. Suozzo et al., "Natural history of hepatitis $\mathrm{C}$ virus carriers with persistently normal aminotransferase levels," Gastroenterology, vol. 118, no. 4, pp. 760764, 2000.

[26] S. Rossi, F. De Filippi, S. Saibeni et al., "A 15-Yr prospective histological follow-up study in patients with persistently normal aminotransferase levels (PNAL) carrying HCV infection," American Journal of Gastroenterology, vol. 102, no. 11, pp. 2604-2606, 2007.

[27] M. G. Rumi, F. De Filippi, M. F. Donato, E. Del Ninno, and M. Colombo, "Progressive hepatic fibrosis in healthy carriers of hepatitis C virus with a transaminase breakthrough," Journal of Viral Hepatitis, vol. 9, no. 1, pp. 71-74, 2002.

[28] S. Raimondi, S. Bruno, M. U. Mondelli, and P. Maisonneuve, "Hepatitis $\mathrm{C}$ virus genotype $\mathrm{lb}$ as a risk factor for hepatocellular carcinoma development: a meta-analysis," Journal of Hepatology, vol. 50, no. 6, pp. 1142-1154, 2009.

[29] S. Bruno, M. Zuin, A. Crosignani et al., "Predicting mortality risk in patients with compensated HCV-induced cirrhosis: a long-term prospective study," American Journal of Gastroenterology, vol. 104, no. 5, pp. 1147-1157, 2009.

[30] S. Bruno, A. Crosignani, C. Facciotto et al., "Sustained virologic response prevents the development of esophageal varices in compensated, child-pugh class A hepatitis C virusinduced cirrhosis. A 12-year prospective follow-up study," Hepatology, vol. 51, no. 6, pp. 2069-2076, 2010.

[31] M. Kobayashi, E. Tanaka, T. Sodeyama, A. Urushihara, A. Matsumoto, and K. Kiyosawa, "The natural course of chronic hepatitis C: a comparison between patients with genotype 1 and 2 hepatitis C viruses," Hepatology, vol. 34, pp. 764-767, 2001.

[32] L. Roffi, A. Ricci, C. Ogliari et al., "HCV genotypes in Northern Italy: a survey of 1368 histologically proven chronic hepatitis C patients," Journal of Hepatology, vol. 29, no. 5, pp. 701-706, 1998.

[33] S. Zeuzem, A. Franke, J. H. Lee, G. Herrmann, B. Rüster, and W. K. Roth, "Phylogenetic analysis of hepatitis $\mathrm{C}$ virus isolates and their correlation to viremia, liver function tests, and histology," Hepatology, vol. 24, no. 5, pp. 1003-1009, 1996.

[34] P. Farci, A. Shimoda, A. Coiana et al., "The outcome of acute hepatitis $\mathrm{C}$ predicted by the evolution of the viral quasispecies," Science, vol. 288, no. 5464, pp. 339-344, 2000. 
[35] B. Soto, A. Sánchez-Quijano, L. Rodrigo et al., "Human immunodeficiency virus infection modifies the natural history of chronic parenterally-acquired hepatitis $\mathrm{C}$ with an unusually rapid progression to cirrhosis," Journal of Hepatology, vol. 26, no. 1, pp. 1-5, 1997.

[36] P. Pontisso, M. Gerotto, L. Benvegnu, L. Chemello, and A. Alberti, "Coinfection by hepatitis B virus and hepatitis C virus," Antiviral Therapy, vol. 3, no. 3, pp. 137-142, 1998.

[37] R. K. Sterling and M. S. Sulkowski, "Hepatitis C virus in the setting of HIV or hepatitis B virus coinfection," Seminars in Liver Disease, vol. 24, no. 2, supplement, pp. 61-68, 2004.

[38] J. R. Pallás, C. Fariñas-Álvarez, D. Prieto, and M. DelgadoRodríguez, "Coinfections by HIV, hepatitis B and hepatitis $\mathrm{C}$ in imprisoned injecting drug users," European Journal of Epidemiology, vol. 15, no. 8, pp. 699-704, 1999.

[39] G. A. Reddy, K. V. Dakshinamurthy, P. Neelaprasad, T. Gangadhar, and V. Lakshmi, "Prevalence of HBV and HCV dual infection in patients on haemodialysis," Indian Journal of Medical Microbiology, vol. 23, no. 1, pp. 41-43, 2005.

[40] A. Aroldi, P. Lampertico, G. Montagnino et al., "Natural history of hepatitis B and C in renal allograft recipients," Transplantation, vol. 79, no. 9, pp. 1132-1136, 2005.

[41] A. Kalinowska-Nowak, M. Bociaga-Jasik, A. Garlicki, and P. Skwara, "Prevalence of hepatotropic viruses HBV and HCV in HIV-infected patients from Southern region of Poland," Acta Virologica, vol. 44, pp. 23-28, 2000.

[42] J. Zhou, G. J. Dore, F. Zhang, P. L. Lim, and Y. M. A. Chen, "Hepatitis B and C virus coinfection in the TREAT Asia HIV Observational Database," Journal of Gastroenterology and Hepatology, vol. 22, no. 9, pp. 1510-1518, 2007.

[43] E. Angelucci, P. Muretto, A. Nicolucci et al., "Effects of iron overload and hepatitis $\mathrm{C}$ virus positivity in determining progression of liver fibrosis in thalassemia following bone marrow transplantation," Blood, vol. 100, no. 1, pp. 17-21, 2002.

[44] V. Di Marco, M. Capra, F. Gagliardotto et al., "Liver disease in chelated transfusion-dependent thalassemics: the role of iron overload and chronic hepatitis C," Haematologica, vol. 93, no. 8, pp. 1243-1246, 2008.

[45] J. P. Zarski, B. Bohn, A. Bastie et al., "Characteristics of patients with dual infection by hepatitis B and C viruses," Journal of Hepatology, vol. 28, no. 1, pp. 27-33, 1998.

[46] J. Crespo, J. L. Lozano, F. De la Cruz et al., "Prevalence and significance of hepatitis $\mathrm{C}$ viremia in chronic active hepatitis B," American Journal of Gastroenterology, vol. 89, no. 8, pp. 1147-1151, 1994.

[47] A. E. Mohamed, M. Ali Al Karawi, and G. A. Mesa, "Dual infection with hepatitis $\mathrm{C}$ and B viruses: clinical and histological study in Saudi patients," Hepato-Gastroenterology, vol. 44, no. 17, pp. 1404-1406, 1997.

[48] J. P. Zarski, B. Bohn, A. Bastie et al., "Characteristics of patients with dual infection by hepatitis B and C viruses," Journal of Hepatology, vol. 28, no. 1, pp. 27-33, 1998.

[49] G. Fattovich, A. Tagger, L. Brollo et al., "Hepatitis C virus infection in chronic hepatitis B virus carriers," Journal of Infectious Diseases, vol. 163, no. 2, pp. 400-402, 1991.

[50] T. L. Fong, A. M. Di Bisceglie, J. G. Waggoner, S. M. Banks, and J. H. Hoofnagle, "The significance of antibody to hepatitis C virus in patients with chronic hepatitis B," Hepatology, vol. 14, no. 1, pp. 64-67, 1991.

[51] H. E. Kuper, M. Tzonou A, and G. A. Kaklamani E, "Hepatitis $B$ and $C$ viruses in the etiology of hepatocellular carcinoma; a study in Greece using third-generation assays," Cancer Causes Control, vol. 2, pp. 171-175, 2000.
[52] E. Kaklamani, D. Trichopoulos, A. Tzonou et al., "Hepatitis $\mathrm{B}$ and $\mathrm{C}$ viruses and their interaction in the origin of hepatocellular carcinoma," Journal of the American Medical Association, vol. 265, no. 15, pp. 1974-1976, 1991.

[53] M. C. Kew, M. C. Yu, M. A. Kedda, A. Coppin, A. Sarkin, and J. Hodkinson, "The relative roles of hepatitis B and C viruses in the etiology of hepatocellular carcinoma in southern African blacks," Gastroenterology, vol. 112, no. 1, pp. 184-187, 1997.

[54] G. D. Kirk, O. A. Lesi, M. Mendy et al., "The Gambia Liver Cancer Study: infection with hepatitis B and C and the risk of hepatocellular carcinoma in West Africa," Hepatology, vol. 39, no. 1, pp. 211-219, 2004.

[55] Panel on Antiretroviral Guidelines for Adults and Adolescents, Guidelines for the use of antiretroviral agents in HIV1-infected adults and adolescents. Department of Health and Human Services, pp.1-166, January 2011.

[56] T. W. Lapinski, A. Parfieniuk, M. Rogalska-Plonska, J. Czajkowska, and R. Flisiak, "Prevalence of cryoglobulinaemia in hepatitis $\mathrm{C}$ virus- and hepatitis $\mathrm{C}$ virus/human immunodeficiency virus-infected individuals: implications for renal function," Liver International, vol. 29, no. 8, pp. 1158-1161, 2009.

[57] J. S. Reingold, C. Wanke, D. P. Kotler et al., "Association of HIV infection and HIV/HCV coinfection with C-reactive protein levels: the fat redistribution and metabolic change in HIV infection (FRAM) study," Journal of Acquired Immune Deficiency Syndromes, vol. 48, no. 2, pp. 142-148, 2008.

[58] C. M. Wyatt, C. Malvestutto, S. G. Coca, P. E. Klotman, and C. R. Parikh, "The impact of hepatitis $\mathrm{C}$ virus coinfection on HIV-related kidney disease: a systematic review and metaanalysis," AIDS, vol. 22, no. 14, pp. 1799-1807, 2008.

[59] M. J. Fischer, C. M. Wyatt, K. Gordon et al., "Hepatitis C and the risk of kidney disease and mortality in veterans with HIV," Journal of Acquired Immune Deficiency Syndromes, vol. 53, no. 2, pp. 222-226, 2010.

[60] R. Bedimo, A. O. Westfall, M. Mugavero, H. Drechsler, N. Khanna, and M. Saag, "Hepatitis C virus coinfection and the risk of cardiovascular disease among HIV-infected patients," HIV Medicine, vol. 11, no. 7, pp. 462-468, 2010.

[61] I. F. De Castro, D. Micheloud, J. Berenguer et al., "Hepatitis $\mathrm{C}$ virus infection is associated with endothelial dysfunction in HIV/hepatitis C virus coinfected patients," AIDS, vol. 24, no. 13, pp. 2059-2067, 2010.

[62] S. Letendre, A. D. Paulino, E. Rockenstein et al., "Pathogenesis of hepatitis $C$ virus coinfection in the brains of patients infected with HIV," Journal of Infectious Diseases, vol. 196, no. 3, pp. 361-370, 2007.

[63] P. Vivithanaporn, F. Maingat, L. T. Lin et al., "Hepatitis $\mathrm{C}$ virus core protein induces neuroimmune activation and potentiates human immunodeficiency virus-1 neurotoxicity," PLoS ONE, vol. 5, no. 9, Article ID e12856, pp. 1-14, 2010.

[64] H. A. Aronow, A. J. Weston, B. B. Pezeshki, and T. S. Lazarus, "Effects of coinfection with HIV and hepatitis C virus on the nervous system," AIDS Reader, vol. 18, no. 1, pp. 43-48, 2008.

[65] C. H. Hinkin, S. A. Castellon, A. J. Levine, T. R. Barclay, and E. J. Singer, "Neurocognition in individuals co-infected with HIV and hepatitis C," Journal of Addictive Diseases, vol. 27, no. 2, pp. 11-17, 2008.

[66] E. Minola, D. Prati, F. Suter et al., "Age at infection affects the long-term outcome of transfusion-associated chronic hepatitis C”, Blood, vol. 99, no. 12, pp. 4588-4591, 2002. 
[67] C. Cammà, S. Bruno, V. Di Marco et al., "Insulin resistance is associated with steatosis in nondiabetic patients with genotype 1 chronic hepatitis C," Hepatology, vol. 43, no. 1, pp. 64-71, 2006.

[68] V. Ortiz, M. Berenguer, J. M. Rayón, D. Carrasco, and J. Berenguer, "Contribution of obesity to hepatitis C-related fibrosis progression," American Journal of Gastroenterology, vol. 97, no. 9, pp. 2408-2414, 2002.

[69] A. Monto, "Hepatitis C and steatosis," Seminars in Gastrointestinal Disease, vol. 13, no. 1, pp. 40-46, 2002.

[70] R. D'Souza, C. A. Sabin, and G. R. Foster, "Insulin resistance plays a significant role in liver fibrosis in chronic hepatitis C and in the response to antiviral therapy," American Journal of Gastroenterology, vol. 100, no. 7, pp. 1509-1515, 2005.

[71] M. Persico, M. Capasso, E. Persico et al., "Suppressor of cytokine signaling 3 (SOCS3) expression and hepatitis C virus-related chronic hepatitis: insulin resistance and response to antiviral therapy," Hepatology, vol. 46, no. 4, pp. 1009-1015, 2007.

[72] M. Persico, R. Russo, E. Persico et al., "SOCS3 and IRS-1 gene expression differs between genotype 1 and genotype 2 hepatitis C virus-infected HepG2 cells," Clinical Chemistry and Laboratory Medicine, vol. 47, no. 10, pp. 1217-1225, 2009.

[73] J. E. Everhart, A. S. Lok, H. Y. Kim et al., "Weight-related effects on disease progression in the hepatitis $\mathrm{C}$ antiviral long-term treatment against cirrhosis trial," Gastroenterology, vol. 137, no. 2, pp. 549-557, 2009.

[74] H. L. Bonkovsky, B. F. Banner, and A. L. Rothman, "Iron and chronic viral hepatitis," Hepatology, vol. 25, no. 3, pp. 759768, 1997.

[75] A. M. Di Bisceglie, H. L. Bonkovsky, S. Chopra et al., "Iron reduction as an adjuvant to interferon therapy in patients with chronic hepatitis $\mathrm{C}$ who have previously not responded to interferon: a multicenter, prospective, randomized, controlled trial," Hepatology, vol. 32, no. 1, pp. 135-138, 2000.

[76] D. Thorburn, G. Curry, R. Spooner et al., "The role of iron and haemochromatosis gene mutations in the progression of liver disease in chronic hepatitis C," Gut, vol. 50, no. 2, pp. 248-252, 2002.

[77] S. Matsuoka, K. Nirei, A. Tamura et al., "Influence of occult hepatitis B virus coinfection on the incidence of fibrosis and hepatocellular carcinoma in chronic hepatitis C," Intervirology, vol. 51, no. 5, pp. 352-361, 2009.

[78] H. L. Bonkovsky, D. Naishadham, R. W. Lambrecht et al., "Roles of iron and HFE mutations on severity and response to therapy during retreatment of advanced chronic hepatitis C," Gastroenterology, vol. 131, no. 5, pp. 1440-1451, 2006.

[79] R. W. Lambrecht, R. K. Sterling, D. Naishadham et al., "Iron levels in hepatocytes and portal tract cells predict progression and outcomes of patients with advanced chronic hepatitis C," Gastroenterology, vol. 140, no. 5, pp. 1490-1500.e3, 2011.

[80] G. Corrao and S. Arico, "Independent and combined action of hepatitis $\mathrm{C}$ virus infection and alcohol consumption on the risk of symptomatic liver cirrhosis," Hepatology, vol. 27, no. 4, pp. 914-919, 1998.

[81] G. Ostapowicz, K. J. R. Watson, S. A. Locarnini, and P. V. Desmond, "Role of alcohol in the progression of liver disease caused by hepatitis C virus infection," Hepatology, vol. 27, no. 6, pp. 1730-1735, 1998.

[82] F. Pessione, F. Degos, P. Marcellin et al., "Effect of alcohol consumption on serum hepatitis $\mathrm{C}$ virus RNA and histological lesions in chronic hepatitis C," Hepatology, vol. 27, no. 6, pp. 1717-1722, 1998.
[83] T. E. Wiley, M. Mccarthy, L. Breidi, M. Mccarthy, and T. J. Layden, "Impact of alcohol on the histological and clinical progression of hepatitis C infection," Hepatology, vol. 28, no. 3, pp. 805-809, 1998.

[84] G. Fattovich, T. Stroffolini, I. Zagni, and F. Donato, "Hepatocellular carcinoma in cirrhosis: incidence and risk factors," Gastroenterology, vol. 127, supplement, pp. S35-S50, 2004.

[85] K. Q. Hu and M. J. Tong, "The long-term outcomes of patients with compensated hepatitis $\mathrm{C}$ virus- related cirrhosis and history of parenteral exposure in the United States," Hepatology, vol. 29, no. 4, pp. 1311-1316, 1999.

[86] L. Benvegnù, M. Gios, S. Boccato, and A. Alberti, "Natural history of compensated viral cirrhosis: a prospective study on the incidence and hierarchy of major complications," Gut, vol. 53, no. 5, pp. 744-749, 2004.

[87] A. Sangiovanni, G. M. Prati, P. Fasani et al., "The natural history of compensated cirrhosis due to hepatitis $\mathrm{C}$ virus: a 17-year cohort study of 214 patients," Hepatology, vol. 43, no. 6, pp. 1303-1310, 2006.

[88] F. Degos, C. Christidis, N. Ganne-Carrie et al., "Hepatitis C virus related cirrhosis: time to occurrence of hepatocellular carcinoma and death," Gut, vol. 47, no. 1, pp. 131-136, 2000.

[89] C. Ripoll, R. J. Groszmann, G. Garcia-Tsao et al., "Hepatic venous pressure gradient predicts development of hepatocellular carcinoma independently of severity of cirrhosis," Journal of Hepatology, vol. 50, no. 5, pp. 923-928, 2009.

[90] K. W. Kim, S. K. Bae, O. H. Lee, M. H. Bae, M. J. Lee, and B. C. Park, "Insulin-like growth factor II induced by hypoxia may contribute to angiogenesis of human hepatocellular carcinoma," Cancer Research, vol. 58, no. 2, pp. 348-351, 1998.

[91] S. Bruno, E. Silini, A. Crosignani et al., "Hepatitis C virus genotypes and risk of hepatocellular carcinoma in cirrhosis: a prospective study," Hepatology, vol. 25, no. 3, pp. 754-758, 1997.

[92] S. Bruno, A. Crosignani, P. Maisonneuve, S. Rossi, E. Silini, and M. U. Mondelli, "Hepatitis C virus genotype $1 \mathrm{~b}$ as a major risk factor associated with hepatocellular carcinoma in patients with cirrhosis: a seventeen-year prospective cohort study," Hepatology, vol. 46, no. 5, pp. 1350-1356, 2007.

[93] Y. Nishise, T. Saito, K. Sugahara et al., "Risk of hepatocellular carcinoma and secondary structure of hepatitis $\mathrm{C}$ virus (HCV) NS3 protein amino-terminus, in patients infected with HCV subtype 1b," Journal of Infectious Diseases, vol. 196, no. 7, pp. 1006-1009, 2007.

[94] L. Benvegnù, M. Gios, S. Boccato, and A. Alberti, "Natural history of compensated viral cirrhosis: a prospective study on the incidence and hierarchy of major complications," Gut, vol. 53, no. 5, pp. 744-749, 2004.

[95] G. D’Amico, G. Garcia-Tsao, and L. Pagliaro, "Natural history and prognostic indicators of survival in cirrhosis: a systematic review of 118 studies," Journal of Hepatology, vol. 44, no. 1, pp. 217-231, 2006.

[96] F. Durand and D. Valla, "Assessment of prognosis of cirrhosis," Seminars in Liver Disease, vol. 28, no. 1, pp. 110-122, 2008.

[97] S. Bruno, T. Stroffolini, M. Colombo et al., "Sustained virological response to interferon- $\alpha$ is with improved outcome in HCV-related cirrhosis: a retrospective study," Hepatology, vol. 45, no. 3, pp. 579-587, 2007.

[98] B. J. Veldt, E. J. Heathcote, H. Wedemeyer et al., "Sustained virologic response and clinical outcomes in patients with chronic hepatitis C and advanced fibrosis," Annals of Internal Medicine, vol. 147, no. 10, pp. 677-684, 2007. 
[99] T. Asselah and P. Marcellin, "New direct-acting antivirals' combination for the treatment of chronic hepatitis C," Liver International, vol. 31, no. 1, supplement, pp. 68-77, 2011.

[100] Y. Shiratori, F. Imazeki, M. Moriyama et al., "Histologic improvement of fibrosis in patients with hepatitis $\mathrm{C}$ who have sustained response to interferon therapy," Annals of Internal Medicine, vol. 132, no. 7, pp. 517-524, 2000.

[101] C. Cammà, D. Di Bona, F. Schepis et al., "Effect of peginterferon alfa-2a on liver histology in chronic hepatitis $\mathrm{C}$ : a meta-analysis of individual patient data," Hepatology, vol. 39, no. 2, pp. 333-342, 2004.

[102] T. Poynard, J. McHutchison, M. Manns et al., "Impact of pegylated interferon alfa-2b and ribavirin on liver fibrosis in patients with chronic hepatitis C," Gastroenterology, vol. 122, no. 5, pp. 1303-1313, 2002.

[103] P. Marcellin, N. Boyer, C. Degott et al., "Long-term histologic and viral changes in patients with chronic hepatitis $\mathrm{C}$ who responded to alpha interferon," Liver, vol. 14, no. 6, pp. 302307, 1994.

[104] S. L. George, B. R. Bacon, E. M. Brunt, K. L. Mihindukulasuriya, J. Hoffman, and A. M. Di Bisceglie, "Clinical, virologic, histologic, and biochemical outcomes after successful HCV therapy: a 5-year follow-up of 150 patients," Hepatology, vol. 49, no. 3, pp. 729-738, 2009.

[105] P. Marcellin, N. Boyer, A. Gervais et al., "Long-term histologic improvement and loss of detectable intrahepatic HCV RNA in patients with chronic hepatitis $\mathrm{C}$ and sustained response to interferon- $\alpha$ therapy," Annals of Internal Medicine, vol. 127, no. 10, pp. 875-881, 1997.

[106] M. Sata, T. Ide, and F. Akiyoshi, "Effects of interferon alpha $2 \mathrm{a}$ on incidence of hepatocellular carcinoma in chronic active hepatitis without cirrhosis," Kurume Medical Journal, vol. 44, pp. 171-177, 1997.

[107] D. T. Y. Lau, D. E. Kleiner, M. G. Ghany, Y. Park, P. Schmio, and J. H. Hoofnagle, "10-year follow-up after interferon- $\alpha$ therapy for chronic hepatitis C," Hepatology, vol. 28, no. 4 I, pp. 1121-1127, 1998.

[108] C. Cammà, V. Di Marco, O. Lo Iacono et al., "Long-term course of interferon-treated chronic hepatitis C," Journal of Hepatology, vol. 28, no. 4, pp. 531-537, 1998.

[109] A. Ajello, M. A. Freni, A. Spadaro et al., "Ten year follow-up of patients with chronic hepatitis C treated with interferon," Hepato-Gastroenterology, vol. 46, no. 28, pp. 2447-2450, 1999.

[110] F. Morisco, R. Marmo, P. Iasevoli et al., "Clinical outcome of chronic hepatitis $\mathrm{C}$ in patients treated with interferon: comparison between responders and non-responders," Italian Journal of Gastroenterology and Hepatology, vol. 31, no. 6, pp. $454-458,1999$.

[111] A. Gallego, X. Torras, F. J. Sancho-Poch, and J. Enriquez, "Long term follow-up of patient with chronic hepatitis C after IFN therapy," Journal of Hepatology, vol. 34, supplement 1, p. 234, 2001.

[112] E. Giannini, A. Fasoli, F. Botta et al., "Long-term follow up of chronic hepatitis $\mathrm{C}$ patients after $\alpha$-interferon treatment: a functional study," Journal of Gastroenterology and Hepatology, vol. 16, no. 4, pp. 399-405, 2001.

[113] M. Shindo, K. Hamada, Y. Oda, and T. Okuno, "Long-term follow-up study of sustained biochemical responders with interferon therapy," Hepatology, vol. 33, no. 5, pp. 1299-1302, 2001.

[114] M. Swain, M. Y. Lai, M. L. Shiffman et al., "Durability of sustained virological response (SVR) after treatment with peginterferon alfa $2 \mathrm{~A}(40 \mathrm{kD})$ (PEGASYS) alone or in combination with ribavirin (Copegus): results of an ongoing long-term follow-up study," Hepatology, vol. 40, supplement 1, p. 400A, 2004.

[115] B. J. Veldt, G. Saracco, C. Cammà et al., "Long term clinical outcome of chronic hepatitis C patients with sustained virological response to interferon monotherapy," Gut, vol. 53, no. 10, pp. 1504-1508, 2004.

[116] A. Ciancio, A. Smedile, C. Giordanino et al., "Long-term follow-up of previous hepatitis $\mathrm{C}$ virus positive nonresponders to interferon monotherapy successfully retreated with combination therapy: are they really cured?" American Journal of Gastroenterology, vol. 101, no. 8, pp. 1811-1816, 2006.

[117] D. Chavalitdhamrong and T. Tanwandee, "Long-term outcomes of chronic hepatitis $\mathrm{C}$ patients with sustained virological response at 6 months after the end of treatment," World Journal of Gastroenterology, vol. 12, no. 34, pp. 5532-5535, 2006.

[118] E. J. Heathcote, M. L. Shiffman, W. G. E. Cooksley et al., "Peginterferon alfa-2a in patients with chronic hepatitis C and cirrhosis," The New England Journal of Medicine, vol. 343, no. 23, pp. 1673-1680, 2000.

[119] M. P. Manns, J. G. McHutchison, S. C. Gordon et al., "Peginterferon alfa-2b plus ribavirin compared with interferonalfa$2 \mathrm{~b}$ plus ribavirin for initial treatment of chronic hepatitis $\mathrm{C}$ : a randomised trial," The Lancet, vol. 358, no. 9286, pp. 958965, 2001.

[120] M. W. Fried, M. L. Shiffman, K. R. Reddy et al., "Peginterferon alfa-2a plus ribavirin for chronic hepatitis $\mathrm{C}$ virus infection," The New England Journal of Medicine, vol. 347, no. 13, pp. 975-982, 2002.

[121] S. J. Hadziyannis, H. Sette Jr., T. R. Morgan et al., "Peginterferon-alpha2a and ribavirin combination therapy in chronic hepatitis $\mathrm{C}$ : a randomized study of treatment duration and ribavirin dose," Annals of Internal Medicine, vol. 140, no. 5, pp. 346-I67, 2004.

[122] S. Zeuzem, R. Hultcrantz, M. Bourliere et al., "Peginterferon alfa-2b plus ribavirin for treatment of chronic hepatitis $\mathrm{C}$ in previously untreated patients infected with HCV genotypes 2 or 3," Journal of Hepatology, vol. 40, no. 6, pp. 993-999, 2004. 


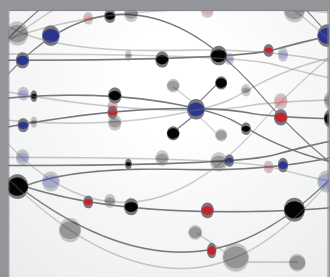

The Scientific World Journal
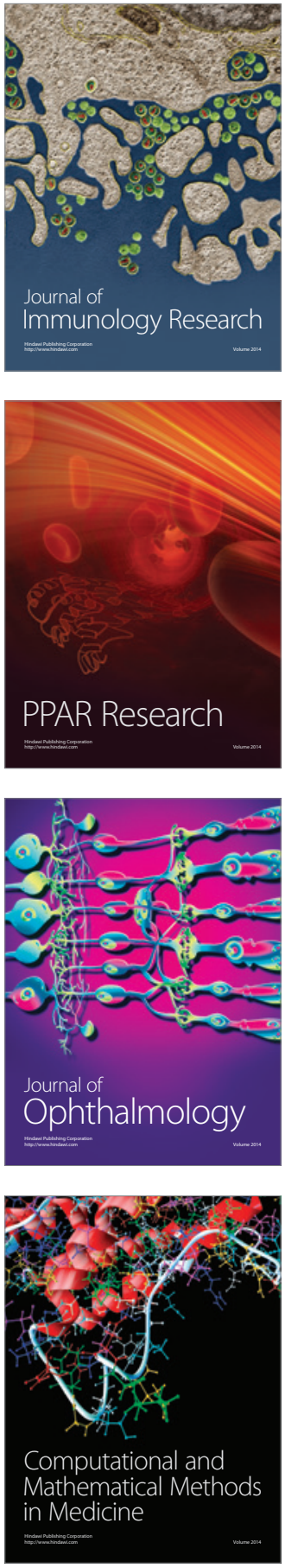

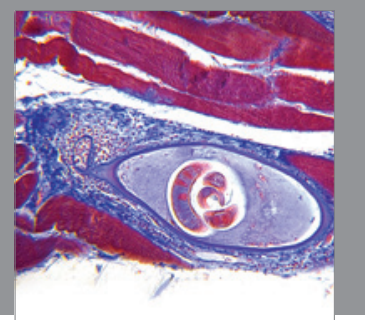

Gastroenterology

Research and Practice
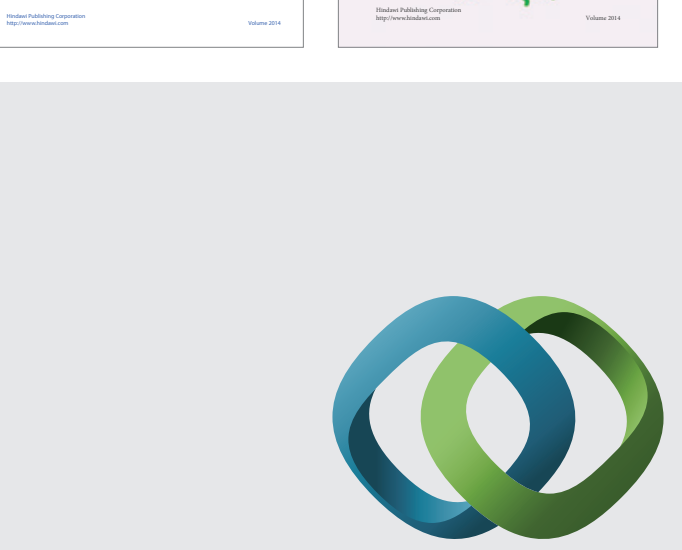

\section{Hindawi}

Submit your manuscripts at

http://www.hindawi.com
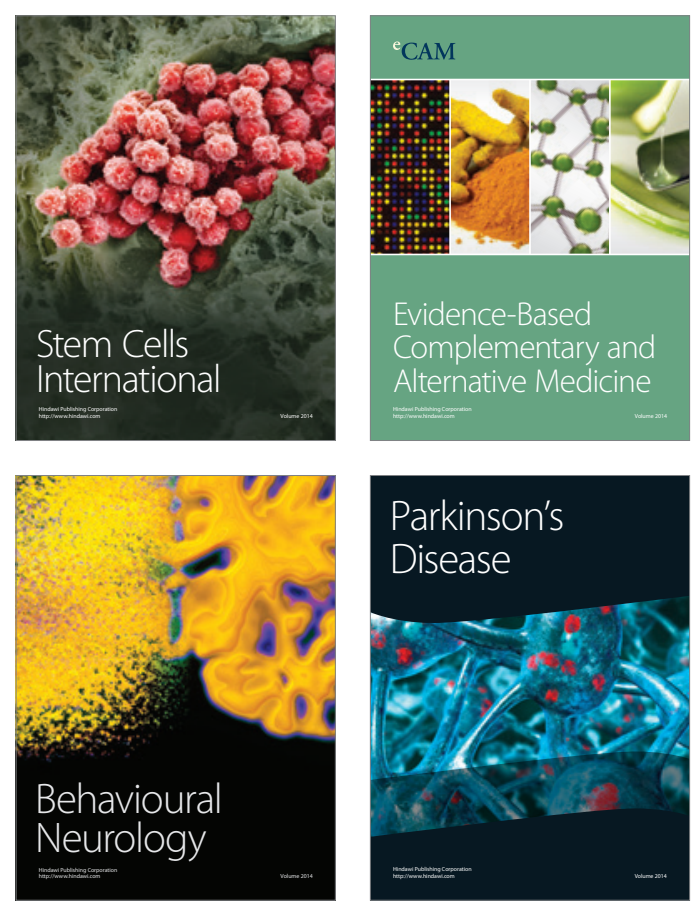

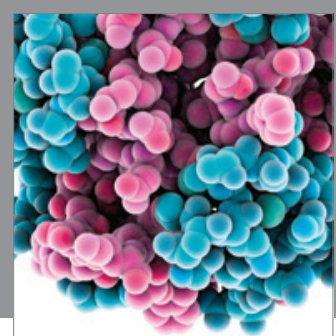

Journal of
Diabetes Research

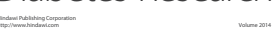

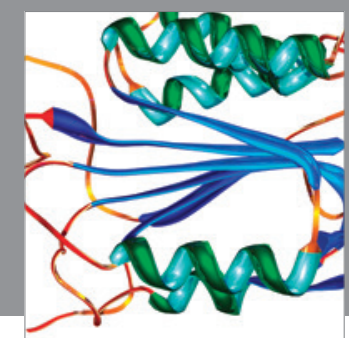

Disease Markers
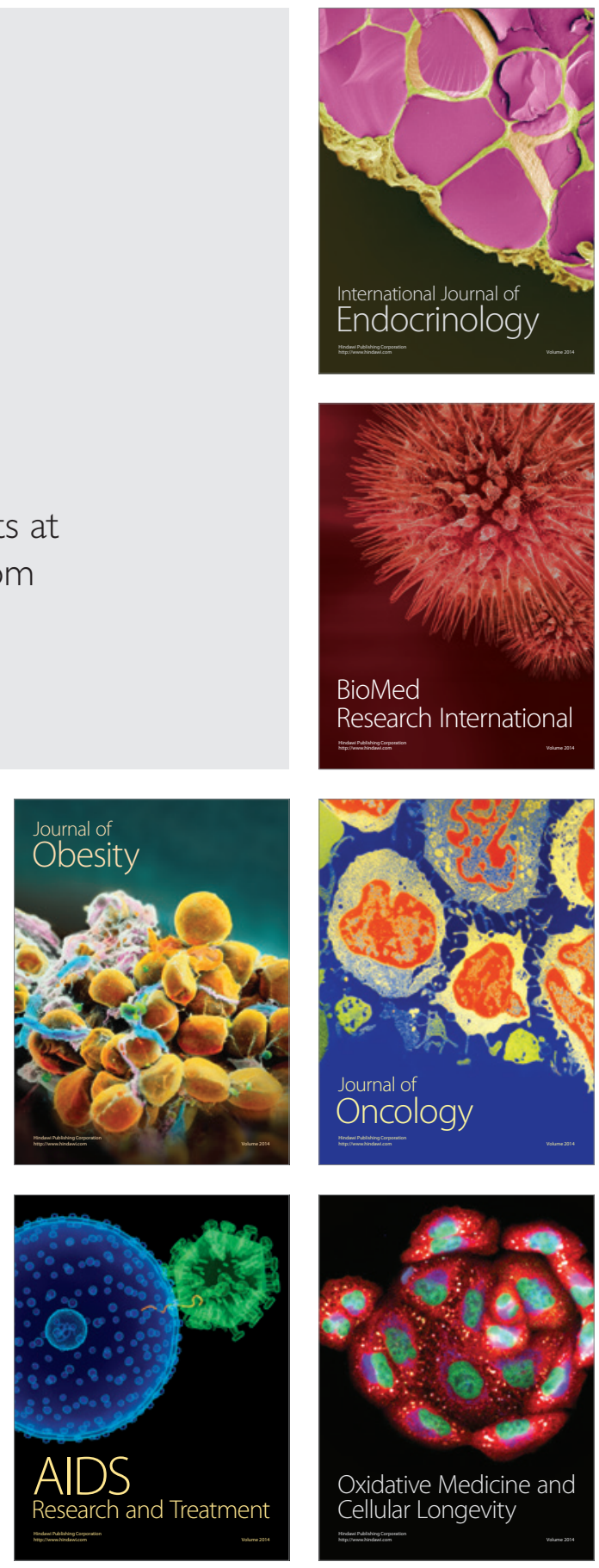